\title{
Transformation of Nitrogen Fertilizers in Greenhouse Experiments
}

\author{
${ }^{1}$ E. NÓTÁS, ${ }^{2} \mathrm{~K}$. DEBRECZENI, ${ }^{2} \mathrm{~K}$. FISCHL and ${ }^{1}$ G. HELTAI \\ ${ }^{1}$ Szent István University, Department of Chemistry and Biochemistry, Gödöllő and \\ ${ }^{2}$ Veszprém University, Georgikon Faculty of Agriculture, Keszthely (Hungary)
}

In intensive crop production technologies a high rate of nitrogen fertilizers is applied, which can be transformed into organic compounds very quickly (NóTÁs et al., 1997). Field crops utilize about $20-80 \%$ of the $\mathrm{N}$ fertilizer directly (FAUST, 1981; HADARDSON, 1990; DEBRECZENI \& SZlovÁK, 1990). The remainder of the fertilizer $\mathrm{N}$ is immobilized either chemically and biologically, or is lost by leaching or denitrification processes and so may cause environmental damages (e.g. soil acidification, nitrate leaching, $\mathrm{NO}_{\mathrm{x}}$ emission contributing to the greenhouse effect). The gaseous $\mathrm{N}$ losses may reach $20 \%$ of the fertilizers applied in ploughed fields (COLBOURN \& DOWDELL, 1984). This loss can be higher $(47-75 \%)$, as it was shown in a three-year period of microplot study with the application of 75-150 kg/ha fertilizer N (HANTING et al., 1990). Nevertheless, the rate of plant $\mathrm{N}$ uptake depends on the crop species and even its varieties, the dose and date of fertilization, and the soil moisture content, etc.

The quantity of immobilized nitrogen can make up for $10-25 \%$ of the applied fertilizer and can be incorporated in various organic nitrogen compounds of the soil, or may be fixed as ammonium $\left(\mathrm{NH}_{4}{ }^{+}\right)$in the crystal lattice of clay minerals. Part of the immobilized organic compounds remobilize again during the vegetation period but their significant portion remains in immobilized organic forms in the soil until harvesting. However, in the following years remobilization of fertilizer $\mathrm{N}$ can be experienced in long-term experiments. Such after-effect experiments are very important when the real plants' nutrient uptake and the soils' nutrient supplying capacity are to be estimated, as it was done in the present study.

The ${ }^{15} \mathrm{~N}$ tracer technique has been used to supply data for dynamics and cumulative values of plant nutrient uptake by the quantitative determination of the ${ }^{15} \mathrm{~N}$-labelled N-source's recovery percent (BREMNER \& KEENEY, 1966; HELTAI \& FÜLEKY, 1992). In pot experiments the field processes can be

Correspondence to: Erika NÓTÁS, Szent István University, Department of Chemistry and Biochemistry, H-2103 Gödöllö, Páter K. út 1. Hungary E-mail: Notas@fau.gau.hu 
modelled properly, but the results do not relate to field conditions directly. This was also proven by SMIRNOW (1970) (cit. DEBRECZENI, 1973.), who compared the transformation and recovery of $\mathrm{N}$ fertilizers in pot and field experiments. In the first year of this pot experiment $60 \%$ of the plant's total $\mathrm{N}$ content was found to originate from the fertilizers, while in field conditions this value was only as much as $40-50 \%$.

Present paper reports about a three-year pot experiment as part of an eightyear long model agroecosystem study, in which a complex ecological approach was applied for studying the $\mathrm{N}$ flows (soil $\mathrm{N}$, plant $\mathrm{N}$ uptake, gaseous $\mathrm{N}$ losses). The after-effect of $\mathrm{N}$ fertilization was also studied. Two- and three-year $\mathrm{N}$ balances were determined at the end of the experiments. Three compartments of cumulative plant $\mathrm{N}$ uptake, fertilizer $\mathrm{N}$ residue in the soil and gaseous losses were analyzed. The dynamic study of the nitrification and denitrification processes was provided by gas sampling with adequate frequency and the determination of gaseous $\mathrm{N}$ losses. The detailed data concerning accumulation of $\mathrm{N}$ containing gases were reported by DEBRECZENI (1995).

\section{Materials and Methods}

In a three-year period (1993-1995) of a longer greenhouse pot experiment the $1^{\text {st }}$ and $2^{\text {nd }}$ years' after-effect of mineral $\mathrm{N}$ fertilization was studied in a cascade system. For the after-effect experiments, all pots - with the exception of controls - were fertilized, and half of the pots were planted in the first year of the 1993-1994-1995 study period, followed by a resowing without further fertilization either in 1994 for the $1^{\text {st }}$, or in 1995 for the $1^{\text {st }}$ and $2^{\text {nd }}$ years' aftereffect studies. So a two year after-effect (set up in 1993) and one year aftereffect (set up in 1994.) can be determined.

The brown forest soil with clay illuviation from Keszthely $\left(\mathrm{pH}_{\mathrm{KCl}}=7.7, \mathrm{C}=\right.$ $1.1 \%, \mathrm{NO}_{3}-\mathrm{N}=17.5 \mathrm{mg} / \mathrm{kg}, \mathrm{NH}_{4}-\mathrm{N}=12 \mathrm{mg} / \mathrm{kg}$, humus $=1.9 \%$ ) was filled in plastic pots (40 kg soil/pot). Gas collecting traps of $1.8 \mathrm{dm}^{3}$ capacity with silicon pipe outlets were placed at a depth of $20 \mathrm{~cm}$ in the soil. The $\mathrm{N}$ fertilizers $\left(\mathrm{KNO}_{3}, \mathrm{NH}_{4} \mathrm{Cl}\right)$ were applied at a rate corresponding to $150 \mathrm{mg} \mathrm{N} / \mathrm{kg}$ soil $(6250$ $\mathrm{mg} \mathrm{N} /$ pot). All experiments were carried out at two soil moisture levels (water holding capacity, $\mathrm{WHC}=65 \%$ and $80 \%$ ) with and without sowing maize hybrids (two Volga and two Pioneer 3722/pot) as test plants. The plants were grown until full ripening. The experiment was carried out with four replications. In one of the replications ${ }^{15} \mathrm{~N}$-labelled fertilizer $\left(5\right.$ atom $\left.\%{ }^{15} \mathrm{~N}\right)$ was applied and the ${ }^{15} \mathrm{~N} /{ }^{14} \mathrm{~N}$ isotopic ratio was determined.

The following parameters were determined in each sample:

- For soil atmosphere analysis $\left(\mathrm{N}_{2}, \mathrm{NO}_{\mathrm{x}}\right.$ gaseous losses): gaseous samples were collected 7-11 times in the different experimental years. The gaseous samples were taken with $\left(5 \mathrm{~cm}^{3}\right)$ syringe in three replications. The composition 
of the $\mathrm{N}$ containing gases $\left(\mathrm{N}_{2}, \mathrm{NO}, \mathrm{NO}_{2}, \mathrm{~N}_{2} \mathrm{O}\right)$ was determined by a Carlo Erba type gas chromatograph. From these data the cumulative gaseous $\mathrm{N}$ losses were calculated.

- For plant fertilizer $\mathrm{N}$ uptake: following the cutting of test plants the different parts (leaves, grain, stalk, shank, tassel, husks) were separated. The plant $\mathrm{N}$ uptake was determined separately in the plant parts and the total $\mathrm{N}$ uptake was calculated by summarizing these data for a pot (4 plants). The total $\mathrm{N}$ content was analyzed by the Kjeldahl-method followed by Parnass-Wagner distillation and titration. The ${ }^{15} \mathrm{~N}$ isotopic analysis was performed by the emission spectrometric method using a microwave induced plasma optical emission spectrometer (HELTAI \& JÓZSA, 1995; HeLTAI et al., 1995). The ${ }^{15} \mathrm{~N}$-concentrations were separately determined for both maize hybrids in the experiment set up in 1993.

- The change of the concentration of mineral $\mathrm{N}$ forms (ammonium- and nitrate-N) of the soil was determined by $1 \mathrm{M} \mathrm{KCl}$ extraction method followed by distillation and titration according to BREMNER \& KEENEY (1966). In these extracts the ${ }^{15} \mathrm{~N}$-atom $\%$ was also determined.

The nitrogen amounts originating from the fertilizer were calculated in two ways: the ${ }^{15} \mathrm{~N}$-traced recovery and the difference calculation method. This difference method was applied for all three compartments (plant $\mathrm{N}$ uptake, soil mineral $\mathrm{N}$, gaseous $\mathrm{N}$ losses). The recovery percentage of fertilizer $\mathrm{N}$ in the plants and fertilizer $\mathrm{N}$ residue in the soil were calculated by the ${ }^{15} \mathrm{~N}$-tracer method. The results of the two methods were also compared.

\section{Results and Conclusions}

The distribution of nitrogen within the soil mineral $\mathrm{N}$ compartment, the plant $\mathrm{N}$ uptake and the gaseous losses in the year the experiment was set up are shown in $\mathrm{mg} /$ pot unit in Table 1, while distribution of $\mathrm{N}$ in the first- and second year after-effects are presented in Table 2. The two-year (experiment set up in 1994) and the three-year (set up in 1993) balances of gaseous losses and plant $\mathrm{N}$ uptake are shown in Table 3.

The soil mineral $\mathrm{N}$ content of the planted and $\mathrm{N}$ treated pots were several times lower than those of the controls (mainly as a result of the after-effect processes). In planted pots the after-effect differences were not significant between the controls and the treated samples, which is a supposed consequence of the immobilization or the usage of fertilizer $\mathrm{N}$ from the soil-plant system through plant $\mathrm{N}$ uptake and gaseous $\mathrm{N}$ losses. On the contrary, in the unplanted and $\mathrm{N}$ treated pots the soil mineral $\mathrm{N}$ contents were significantly higher than in the controls. It was also observed that in the unplanted pots - as compared to the planted pots - the soil mineral $\mathrm{N}$ contents were obviously higher, due to the absence of any $\mathrm{N}$ uptake by plants. 
Table 1

The distribution of nitrogen in the year the experiments were set up (mg/pot)

\begin{tabular}{|l|r|r|r|r|r|r|r|r|r|}
\hline Treat- & \multicolumn{3}{|c|}{ Soil mineral N } & \multicolumn{3}{|c|}{ Gaseous losses } & \multicolumn{3}{|c|}{ Plant N uptake } \\
\cline { 2 - 9 } ment* & \multicolumn{1}{|c|}{1993} & 1994 & 1995 & 1993 & 1994 & 1995 & 1993 & 1994 & 1995 \\
\hline 1. & 456 & 431 & 274 & 132 & 130 & 125 & 1171 & 1975 & 677 \\
2. & 383 & 515 & 433 & 964 & 970 & 951 & 4772 & 6027 & 6354 \\
3. & 346 & 377 & 442 & 912 & 877 & 853 & 4237 & 5905 & 4974 \\
4. & 3130 & 3293 & 3122 & 93 & 131 & 93 & - & - & - \\
5. & 7923 & 3834 & 12886 & 1559 & 1593 & 1576 & - & - & - \\
6. & 8828 & 4679 & - & 1483 & 1447 & 1472 & - & - & - \\
7. & 291 & 356 & 294 & 122 & 114 & 112 & 1257 & 2192 & 821 \\
8. & 434 & 656 & 395 & 929 & 903 & 941 & 4772 & 6135 & 6283 \\
9. & 378 & 479 & 400 & 851 & 822 & 824 & 4265 & 6877 & 3749 \\
10. & 2715 & 3960 & 6477 & 81 & 62 & 77 & - & - & - \\
11. & 9384 & 7358 & 15814 & 1489 & 1423 & 1475 & - & - & - \\
12. & 10926 & 11180 & 15673 & 1435 & 1368 & 1420 & - & - & - \\
\hline
\end{tabular}

Treatments: 1-3: with plant, 80\% WHC, 4-6: without plant, 80\% WHC, 7-9: with plant, 65\% WHC, 10-12: without plant, 65\% WHC. Fertilizers applied: None (control) Treatment No. 1, 4. 7. 10; $\mathrm{KNO}_{3}$ : 2., 5., 8., 11; $\mathrm{NH}_{4} \mathrm{Cl}: 3 ., 6 ., 9 ., 12$.

Table 2

The distribution of $\mathrm{N}$ in the $1^{\text {st }}$ year (experiments set up in 1993 and 1994) and $2^{\text {nd }}$ year (experiment set up in 1993) after-effects (mg/pot)

\begin{tabular}{|c|c|c|c|c|c|c|c|c|c|}
\hline \multirow{3}{*}{$\begin{array}{l}\text { Treat- } \\
\text { ment* }\end{array}$} & \multicolumn{6}{|c|}{$1^{\text {st }}$ year after-effect } & \multicolumn{3}{|c|}{$2^{\text {nd }}$ year after-effect } \\
\hline & 1993 & 1994 & 1993 & 1994 & 1993 & 1994 & 1993 & 1993 & 1993 \\
\hline & \multicolumn{2}{|c|}{ Soil mineral $\mathrm{N}$} & \multicolumn{2}{|c|}{ Gaseous loss } & \multicolumn{2}{|c|}{ Plant $\mathrm{N}$ uptake } & $\begin{array}{c}\text { Soil } \\
\mathrm{N}\end{array}$ & $\begin{array}{l}\text { Gas. } \\
\text { loss }\end{array}$ & $\begin{array}{l}\text { Plant } \\
\text { uptake }\end{array}$ \\
\hline 1. & 270 & 423 & 123 & 121 & 976 & 1305 & 316 & 42 & 1042 \\
\hline 2. & 273 & 475 & 562 & 519 & 859 & 1505 & 366 & 135 & 1217 \\
\hline 3. & 366 & 424 & 449 & 454 & 680 & 1421 & 382 & 118 & 1052 \\
\hline 4. & 3531 & 5064 & 74 & 68 & - & - & 13949 & 48 & - \\
\hline 5. & 4739 & - & 882 & 896 & - & - & 12939 & 207 & - \\
\hline 6. & 6989 & - & 800 & 751 & - & - & 16863 & 185 & - \\
\hline 7. & 297 & 427 & 122 & 101 & 1032 & 1172 & 306 & 35 & 1014 \\
\hline 8. & 267 & 409 & 481 & 469 & 1152 & 1852 & 374 & 117 & 872 \\
\hline 9. & 289 & 376 & 357 & 415 & 823 & 1503 & 426 & 102 & 715 \\
\hline 10. & 6692 & 18268 & 51 & 52 & - & - & 11392 & 36 & - \\
\hline 11. & - & 23382 & 827 & 687 & - & - & - & 181 & - \\
\hline 12. & 12295 & 24876 & 766 & 672 & - & - & 16637 & 171 & - \\
\hline
\end{tabular}

Treatments: See Table 1.

The amount of developed $\mathrm{N}$ containing gases (calculated in $\mathrm{mg} \mathrm{N} /$ pot) was significantly higher in all fertilizer treatments than in the control samples. The amount of molecular $\mathrm{N}_{2}$ gas - as compared to other $\mathrm{N}$ containing gas forms - 
Table 3

Two-year and three-year nitrogen balances (mg/pot) in the experiment set up in 1994 and 1993, respectively

\begin{tabular}{|c|c|c|c|c|c|c|c|c|c|}
\hline \multirow{3}{*}{$\begin{array}{l}\text { Treat- } \\
\text { ment* }\end{array}$} & \multicolumn{2}{|c|}{ 2-year balance } & \multicolumn{2}{|c|}{ 3-year balance } & \multirow{3}{*}{$\begin{array}{l}\text { Treat- } \\
\text { ment* }\end{array}$} & \multicolumn{2}{|c|}{ 2-year balance } & \multicolumn{2}{|c|}{ 3-year balance } \\
\hline & 1994 & 1994 & 1993 & 1993 & & 1994 & 1994 & 1993 & 1993 \\
\hline & $\begin{array}{l}\text { Gas. } \\
\text { loss }\end{array}$ & $\begin{array}{c}\text { Plant } \\
\text { uptake }\end{array}$ & $\begin{array}{l}\text { Gas. } \\
\text { loss }\end{array}$ & $\begin{array}{c}\text { Plant } \\
\text { uptake }\end{array}$ & & $\begin{array}{l}\text { Gas. } \\
\text { loss }\end{array}$ & $\begin{array}{c}\text { Plant } \\
\text { uptake }\end{array}$ & $\begin{array}{l}\text { Gas. } \\
\text { loss }\end{array}$ & $\begin{array}{c}\text { Plant } \\
\text { uptake }\end{array}$ \\
\hline 1. & 251 & 3280 & 297 & 3189 & 7. & 215 & 3364 & 279 & 3303 \\
\hline 2. & 1489 & 7532 & 1661 & 6848 & 8. & 1372 & 7987 & 1527 & 6796 \\
\hline 3. & 1331 & 7326 & 1479 & 5969 & 9. & 1237 & 8380 & 1310 & 5803 \\
\hline 4. & 199 & - & 215 & - & 10. & 114 & - & 168 & - \\
\hline 5. & 2489 & - & 2648 & - & 11. & 2110 & - & 2497 & - \\
\hline 6. & 2198 & - & 2468 & - & 12. & 2040 & - & 2372 & - \\
\hline
\end{tabular}

Treatment: See Table 1

was the highest in each case, which is related to a more intensive denitrification in case of $\mathrm{KNO}_{3}$ treatments as compared to $\mathrm{NH}_{4} \mathrm{Cl}$ treatments. In the unplanted samples the gaseous loss was significantly higher than in the planted samples.

The plant $\mathrm{N}$ uptake was significantly higher in the $\mathrm{N}$ fertilizer treatments than in the controls.

The distribution of fertilizer $\mathrm{N}$ between the different compartments (soil mineral $\mathrm{N}$, gaseous losses, plant $\mathrm{N}$ uptake) calculated on the basis of the difference method (as percentage of applied fertilizer $\mathrm{N}$ ) is shown in the first year of the experiment (Table 4), and in the after-effects (Table 5). Two- and three-year balances of the plant $\mathrm{N}$ uptake are given in Table 6 . The recovery of fertilizer $\mathrm{N}$ in the plants and fertilizer $\mathrm{N}$ residue in the soils, calculated on the basis of the ${ }^{15} \mathrm{~N}$-tracer method, are presented in Tables 7 and 8 for the experiment set in 1993 .

Table 4

The distribution of fertilizer $\mathrm{N}$ calculated on the basis of the difference method (as \% of applied N) in the experiments set up in 1993, 1994 and 1995

\begin{tabular}{|l|r|r|r|r|r|r|r|r|r|}
\hline \multirow{2}{*}{$\begin{array}{l}\text { Treat- } \\
\text { ment }\end{array}$} & \multicolumn{3}{|c|}{ Soil mineral N, \% } & \multicolumn{3}{c|}{ Gaseous losses, \% } & \multicolumn{3}{c|}{ Plant N uptake, \% } \\
\cline { 2 - 9 } & 1993 & 1994 & 1995 & 1993 & 1994 & 1995 & 1993 & 1994 & 1995 \\
\hline 2. & - & 1 & 3 & 13 & 13 & 13 & 57 & 65 & 90 \\
3. & - & - & 3 & 12 & 12 & 12 & 49 & 63 & 68 \\
5. & 76 & 9 & 155 & 23 & 23 & 24 & & & \\
6. & 91 & 22 & - & 22 & 21 & 22 & & & \\
8. & 2 & 5 & 2 & 13 & 13 & 13 & 56 & 63 & 87 \\
9. & 1 & 2 & 2 & 12 & 11 & 11 & 48 & 75 & 47 \\
11. & 106 & 54 & 149 & 22 & 22 & 22 & & & \\
12. & 131 & 115 & 146 & 22 & 21 & 21 & & & \\
\hline
\end{tabular}

Treatments: See Table 1 
Table 5

The distribution of fertilizer $\mathrm{N}$ calculated on the basis of the difference method (as \% of applied N) in the $1^{\text {st }}$ year (experiments set up in 1993 and 1994) and $2^{\text {nd }}$ year (experiment set up in 1993) after-effects

\begin{tabular}{|c|c|c|c|c|c|c|c|c|c|}
\hline \multirow{3}{*}{$\begin{array}{l}\text { Treat- } \\
\text { ment* }\end{array}$} & \multicolumn{6}{|c|}{$1^{\text {st }}$ year after-effect } & \multicolumn{3}{|c|}{$2^{\text {nd }}$ year after-effect } \\
\hline & 1993 & 1994 & 1993 & 1994 & 1993 & 1994 & 1993 & 1993 & 1993 \\
\hline & \multicolumn{2}{|c|}{ Soil mineral $\mathrm{N}$} & \multicolumn{2}{|c|}{ Gaseous loss } & \multicolumn{2}{|c|}{ Plant N uptake } & $\begin{array}{c}\text { Soil } \\
\mathrm{N}\end{array}$ & $\begin{array}{l}\text { Gas. } \\
\text { loss }\end{array}$ & $\begin{array}{l}\text { Plant } \\
\text { uptake }\end{array}$ \\
\hline 2. & 0 & 1 & 7 & 6 & & 3 & 1 & 2 & 3 \\
\hline 3. & 2 & 0 & 5 & 5 & & 2 & 1 & 1 & 0 \\
\hline 5. & 19 & - & 13 & 13 & & & & 3 & \\
\hline 6. & 55 & 123 & 12 & 11 & & & 46 & 4 & \\
\hline 8. & & & 6 & 6 & 2 & 11 & 1 & 1 & \\
\hline 9. & & & 4 & 5 & & 5 & 2 & 1 & \\
\hline 11. & - & 81 & 12 & 11 & & & - & 3 & \\
\hline 12. & 89 & 105 & 11 & 10 & & & 84 & 3 & \\
\hline
\end{tabular}

Treatments: See Table 1

Table 6

Two-year and three-year nitrogen balances (mg/pot) in the experiment set up in 1994 and 1993, respectively

\begin{tabular}{|l|c|c|c|c|c|c|}
\hline \multirow{2}{*}{$\begin{array}{c}\text { Treat- } \\
\text { ment }\end{array}$} & \multicolumn{2}{|c|}{ Two-year N balance (set up in 1994) } & \multicolumn{3}{c|}{ Three-year N balance (set up in 1993) } \\
\cline { 2 - 7 } & $\begin{array}{c}\text { Gaseous } \\
\text { losses }\end{array}$ & $\begin{array}{c}\text { Plant N } \\
\text { uptake }\end{array}$ & Sum & $\begin{array}{c}\text { Gaseous } \\
\text { losses }\end{array}$ & $\begin{array}{c}\text { Plant N } \\
\text { uptake }\end{array}$ & Sum \\
\hline 2. & 20 & 68 & 87 & 22 & 60 & 82 \\
3. & 17 & 64 & 82 & 19 & 49 & 68 \\
5. & 36 & & 36 & 39 & & 39 \\
6. & 32 & & 32 & 38 & & 38 \\
8. & 18 & 74 & 92 & 20 & 58 & 78 \\
9. & 16 & 80 & 96 & 16 & 48 & 64 \\
11. & 32 & & 32 & 38 & & 38 \\
12. & 31 & & 31 & 36 & & 36 \\
\hline
\end{tabular}

Treatments: See Table 1

The portion of fertilizer $\mathrm{N}$ remaining in the soil in mineral form was very low in the planted pots. At the end of the first year, these values - calculated on the basis of the ${ }^{15} \mathrm{~N}$-tracer technique - changed and ranged between $0.2-0.8 \%$ (as \% of the applied N) (Table 7). These values decreased continuously during the after-effect. The results of the difference calculation method showed similar trends (Tables 4 and 5). In the unplanted pots the mineral $\mathrm{N}$ amounts in the soil originating from the fertilizer - on the basis of the ${ }^{15} \mathrm{~N}$-tracer technique - ranged between $32 \%$ and more than $100 \%$ at the end of the first year (Table 7), and were $34-47 \%$ in the $1^{\text {st }}$ year after-effect (Table 8 ). The mineral $\mathrm{N}$ residue of 
fertilizer $\mathrm{N}$ in the soil, calculated on the basis of the difference method (Table 4), was significantly higher, probably due to the "priming effect" of the fertilizers, which results in a virtual excess-recovery through the accelerated mobilization of soil organic N (KUDEYAROV, 1989).

Table 7

The distribution of fertilizer $\mathrm{N}$ between the different compartments, calculated on the basis of the ${ }^{15} \mathrm{~N}$ recoveries in 1993

\begin{tabular}{|c|c|c|c|c|c|c|c|c|}
\hline \multirow{3}{*}{$\begin{array}{l}\text { Treat- } \\
\text { ment }\end{array}$} & \multirow{2}{*}{\multicolumn{2}{|c|}{ Soil mineral N }} & \multicolumn{4}{|c|}{ Plant $\mathrm{N}$ uptake } & \multirow{2}{*}{\multicolumn{2}{|c|}{ Plant $\mathrm{N}$ uptake }} \\
\hline & & & \multicolumn{2}{|c|}{ Volga } & \multicolumn{2}{|c|}{ Pioneer } & & \\
\hline & $\mathrm{mg} /$ pot & $\begin{array}{l}\% \\
*\end{array}$ & $\begin{array}{c}\mathrm{mg} / \\
\text { 2plants }\end{array}$ & $\begin{array}{l}\% \\
* *\end{array}$ & $\begin{array}{c}\mathrm{mg} / \\
\text { 2plants }\end{array}$ & $\begin{array}{l}\% \\
* *\end{array}$ & $\mathrm{mg} / \mathrm{pot}$ & $\begin{array}{c}\% \\
* * *\end{array}$ \\
\hline 2. & 24 & 0,4 & 1796 & 57 & 1411 & 45 & 3207 & 51 \\
\hline 3. & 14 & 0,2 & 1200 & 38 & 1305 & 42 & 2505 & 40 \\
\hline 5. & 4419 & 71 & - & - & - & - & - & - \\
\hline 6. & 5423 & 87 & - & - & - & - & - & - \\
\hline 8. & 48 & 0,8 & 1996 & 64 & 986 & 32 & 2982 & 48 \\
\hline 9. & 11 & 0,2 & 1438 & 46 & 763 & 24 & 2201 & 35 \\
\hline 10. & 6721 & 108 & - & - & - & - & - & - \\
\hline 11. & 2029 & 32 & - & - & - & - & - & - \\
\hline
\end{tabular}

$*$ : the remainder of fertilizer $\mathrm{N}$ (as the $\%$ of applied $\mathrm{N}$ ); **: recovery of fertilizer $\mathrm{N}$ (as the $\%$ of half of the applied $\mathrm{N}) ; * * *$ recovery of fertilizer $\mathrm{N}$ (as the $\%$ of applied $\mathrm{N}$ )

Table 8

The remainder of fertilizer $\mathrm{N}$ in mineral $\mathrm{N}$ form in the after-effects calculated on the basis of the ${ }^{15} \mathrm{~N}$-tracer technique in the experiment set up in 1993

\begin{tabular}{|c|c|c|c|c|c|c|c|c|c|}
\hline \multirow{3}{*}{$\begin{array}{l}\text { Treat- } \\
\text { ment }\end{array}$} & \multicolumn{4}{|c|}{ Soil mineral $\mathrm{N}$} & \multirow{3}{*}{$\begin{array}{l}\text { Treat- } \\
\text { ment }\end{array}$} & \multicolumn{4}{|c|}{ Soil mineral N } \\
\hline & \multicolumn{2}{|c|}{$1^{\text {st }}$ year } & \multicolumn{2}{|c|}{$2^{\text {nd }}$ year } & & \multicolumn{2}{|c|}{$1^{\text {st }}$ year } & \multicolumn{2}{|c|}{$2^{\text {nd }}$ year } \\
\hline & $\begin{array}{l}\mathrm{mg} / \\
\text { pot }\end{array}$ & $\%$ & $\begin{array}{l}\mathrm{mg} / \\
\text { pot }\end{array}$ & $\%$ & & $\begin{array}{l}\mathrm{mg} / \\
\text { pot }\end{array}$ & $\%$ & $\begin{array}{l}\mathrm{mg} / \\
\text { pot }\end{array}$ & $\%$ \\
\hline 2. & 8 & 0,1 & 5 & 0,1 & 8. & 9 & 0,1 & 19 & 0,3 \\
\hline 3. & 9 & 0,1 & 15 & 0,2 & 9. & 8 & 0,1 & 11 & 0,2 \\
\hline 5. & - & - & - & - & 11. & 2148 & 34 & - & - \\
\hline 6. & 2392 & 38 & - & - & 12. & 2946 & 47 & - & - \\
\hline
\end{tabular}

The cumulative gaseous loss was calculated on the basis of difference method. Results of the 1993-1994-1995 experiments showed similar trends. The quantities of gaseous losses were different in the planted and in the unplanted samples. In the first year of the experiment with plant, the gaseous loss changed between 11-13\% (Table 4) and in the after-effects between 1-7\% (Table 5), while in the experiment without plant the value doubled to $21-24 \%$ 
in the first year, and $3-13 \%$ in the after-effects. On the basis of the summarized three-year balance, the gaseous loss in the planted and unplanted pots was 16$22 \%$ and $36-39 \%$, respectively (Table 6). The gaseous loss was higher in $\mathrm{KNO}_{3}$ treatments than in $\mathrm{NH}_{4} \mathrm{Cl}$ treatments. It was found that the gaseous loss was not influenced significantly by soil moisture, but in most cases higher values were measured at $\mathrm{WHC}=80 \%$ than at $\mathrm{WHC}=65 \%$.

The plant $\mathrm{N}$ uptake was found to depend significantly on the fertilizer $\mathrm{N}$ form, but it was not influenced significantly by soil moisture. The recovery of fertilizer $\mathrm{N}$ in the plants varied between $47-90 \%$ of the applied $\mathrm{N}$ on the basis of the difference method in the year the experiment was set up (Table 4), but the typical value was not more than $70 \%$. In the $1^{\text {st }}$ and the $2^{\text {nd }}$ year of aftereffects these values were very low $(0-11 \%)$ (Table 5) as a consequence of the usage of the significant amount of fertilizer $\mathrm{N}$ from the soil-plant system during the first year. The recovery of fertilizer $\mathrm{N}$ in the plants ranged between $48-80 \%$ during the two and three years (Table 6). It was observed that the maize hybrids (Volga and Pioneer 3732) utilized nitrate-N (56-90\%) better than ammonium-N $(47-75 \%)$. The recovery of fertilizer $\mathrm{N}$ in the plants was determined - in addition to the difference method - by the ${ }^{15} \mathrm{~N}$-tracer technique as well, in the experiment set up in 1993. The amount of plant $\mathrm{N}$ uptake - on the basis of the difference method - was slightly higher (by 6-13\%) (Table 4) than that obtained by the ${ }^{15} \mathrm{~N}$-tracer method (35-51\%) (Table 7). The results obtained by both methods show agreement in the following: the maize hybrids together utilized more from the $\mathrm{KNO}_{3}$-fertilizer, and the plant $\mathrm{N}$ uptake was higher at higher soil moisture $(\mathrm{WHC}=80 \%$ ) in both fertilizer treatments. The Volga hybrid utilized more fertilizer $\mathrm{N}$ at $\mathrm{WHC}=65 \%$, while the Pioneer at $\mathrm{WHC}=$ $80 \%$. It can also be concluded that the $\mathrm{N}$ uptake is affected by the variety of the plants, as $\mathrm{N}$ uptake was higher in case of the Volga hybrid than in the Pioneer. Considering the values of plant $\mathrm{N}$ uptake and gaseous loss it can also be concluded that $20-40 \%$ of the applied $\mathrm{N}$ remains in the soil at the end of the first year. These values changed between $10-20 \%$ in the $1^{\text {st }}$ year after-effect and between $5-15 \%$ in the $2^{\text {nd }}$ year after-effect.

\section{Summary}

The primary $\left(1^{\text {st }}\right.$ year $)$ and the after-effects $\left(2^{\text {nd }}, 3^{\text {rd }}\right.$ year $)$ of $\mathrm{N}$ fertilizers $\left(\mathrm{KNO}_{3}, \mathrm{NH}_{4} \mathrm{Cl}\right)$ on the soil-plant-atmosphere system were studied in a threeyear greenhouse pot experiment with and without maize plants. The two- and three-year balances of the fertilizer $\mathrm{N}$ uptake and gaseous $\mathrm{N}$ losses were also analyzed. The cumulative values of the gaseous losses showed a similar trend in all years, significant differences were not obtained. On the basis of the threeyear balance, the gaseous loss in the planted and unplanted pots was $18-22 \%$ and about $37-39 \%$, respectively. Consequently, there was a $50 \%$ decrease in 
denitrificated gaseous losses of fertilizer $\mathrm{N}$ due to plant $\mathrm{N}$ uptake. The cumulative gaseous loss, calculated by the difference method, was significantly higher in cases of $\mathrm{KNO}_{3}$ applications than in $\mathrm{NH}_{4} \mathrm{Cl}$ treatments, as an assumed consequence of the intensive denitrification. It was found that the gaseous loss was not influenced by soil moisture.

In contrast to the gaseous losses, the values of plant $\mathrm{N}$ uptake and soil mineral $\mathrm{N}$ content showed significant differences in the years studied, as a result of the quick transformation of mineral $\mathrm{N}$ to organic $\mathrm{N}$, the non-complete homogenization of the total soil amount, the seasonal climatic differences in the greenhouse during the years studied, and consequently the different microbiological activity.

The plant $\mathrm{N}$ uptake was found to depend significantly on the fertilizer $\mathrm{N}$ form. Results obtained by the difference method and the ${ }^{15} \mathrm{~N}$-tracer technique were very similar. In the case of $\mathrm{KNO}_{3}$ treatment and higher soil moisture $(\mathrm{WHC}=80 \%)$ plant $\mathrm{N}$ uptake was more intensive, ranging between $48-57 \%$ (calculated by the difference method), and $35-51 \%$ (calculated by the ${ }^{15} \mathrm{~N}$ tracer method) in the first year (1993). It can be concluded that $60-100 \%$ of the fertilizer $\mathrm{N}$ was used from the soil by plant uptake and gaseous losses, which depends mainly on the treatments and the soil moisture during the first year. These values changed between $7-17 \%$ in the $1^{\text {st }}$ year after-effect and between $1-5 \%$ in the $2^{\text {nd }}$ year after-effect.

Key words: soil mineral $\mathrm{N}$, gaseous $\mathrm{N}$ losses, plant $\mathrm{N}$ uptake, $\mathrm{N}$ balances, ${ }^{15} \mathrm{~N}$ tracer technique

The present study was supported by the National Scientific Research Fund (OTKA) (project numbers: 24146, 35189).

\section{References}

BREMNER, J. M. \& KeENEY, D. R., 1966. Determination and isotope-ratio analysis of different forms of nitrogen in soils: 3 . Exchangeable ammonium, nitrate, and nitrite by extraction-distillation methods. Soil Sci. Soc. Amer. Proc. 30. 504-507.

Colbourn, P. \& Dowdell, R. J., 1984. Denitrification in field soils. Plant and Soil. 76. $213-226$.

DEBRECZENI, B., 1973. Agrochemical aspects of major correlations between nutrients and water supply. (In Hungarian) Doctoral dissertation. Gödöllő

DeBRECZENI, K., 1995. Effect of N fertilization on the N-containing gases of the soil. (In Hungarian) Agrokémia és Talajtan. 44. 299-306.

Debreczeni, K. \& Szlovák, S., 1990. Dynamics of nitrogen uptake of maize (Zea mays L.). In: Proc. Intern. Symp. on the Use of Stable Isotopes in Plant Nutrition, Soil Fertility and Environmental Studies. 102-104. IAEA. Vienna. 
FAUST, H., 1981. Nitrogen-15 in Agriculture: 1978-1980. ZFI Mitteilungen No. 49. The Central Institute for Isotope and Radiation Research. Leipzig,

HADARDSON, G., 1990. Use of Nuclear Techniques in Studies of Soil-Plant Relationships. International Atomic Energy Agency. Vienna

Hanting, Z., ZhifEn, G., \& GuOGING, B., 1990. A study on the fate of nitrogenous fertilizer and its influence on the yield of crops in cotton-wheat double harvesting system by using ${ }^{15}$ N. In: Proc. Intern. Symposium on the Use of Stable Isotopes in Plant Nutrition, Soil Fertility and Environmental Studies. IAEA. Vienna. 6-7.

Heltai, GY. \& FÜLEKY, GY., 1992. Soil analysis and nutrition capacity. Microchemical Journal. 46. 4-19.

Heltai, Gy. \& JózSA, T., 1995. ${ }^{15} \mathrm{~N}$-tracer technique with the MIP-OES detection of stable N-isotopes for soil ecological studies. Microchemical Journal. 51. 245-255.

Heltai, Gy. et al., 1995. Evaluation of environmental impact of the $\mathrm{N}$ fertilization on plant-soil-agro-ecosystems, using ${ }^{15} \mathrm{~N}$ tracer technique (Methodological aspects). Bull. Univ. Agric. Sci. Gödöllö. 55-67.

KudeYAROV V. N., 1989. Cikl azota v pochve i effectivnost udobrenii. Nauka. Moscow.

NóTÁs, E. et al., 1997. N-cycle studies in a soil core incubation experiment. Acta Agron. Hungarica. 45. (2) 173-185. 